\title{
Biplot analysis of phenotypic stability in upland cotton genotypes in Mato Grosso
}

\author{
F.J.C. Farias ${ }^{1}$, L.P. Carvalho ${ }^{1}$, J.L. Silva Filho ${ }^{1}$ and P.E. Teodoro ${ }^{2}$ \\ ${ }^{1}$ Centro Nacional de Pesquisa de Algodão, Embrapa Algodão, \\ Campina Grande, PB, Brasil \\ ${ }^{2}$ Departamento de Biologia Geral, Universidade Federal de Viçosa, \\ Viçosa, MG, Brasil \\ Corresponding author: P.E. Teodoro \\ E-mail: eduteodoro@hotmail.com
}

Genet. Mol. Res. 15 (2): gmr. 15028009

Received November 6, 2015

Accepted April 15, 2016

Published May 20, 2016

DOI http://dx.doi.org/10.4238/gmr.15028009

\begin{abstract}
Seed cotton yield is a trait governed by multiple genes that cause changes in the performance of genotypes depending on the cultivation environment. Breeding programs examine the genotype $\mathrm{x}$ environment interaction (GE) using precise statistical methods, such as AMMI (additive main effects and multiplicative interaction) and GGE biplot (genotype main effects + genotype $\mathrm{x}$ environment interaction). The AMMI method combines the analysis of variance and principal components, to adjust the main effects (genotypes and environments) and the effects of GE interaction, respectively. The GGE biplot groups the genotype additive effect together with the multiplicative effect of the GE interaction, and submits both of these to the principal components analysis. The aim of this study was to investigate the association between the AMMI and GGE biplot methods and select cotton genotypes that simultaneously showed high productivity of seed cotton and stability in Mato Grosso environments. Trials were conducted with cotton cultivars in eight environments across Mato Grosso State in the 2008/2009 crop season. The experiment used a randomized block design with 16 genotypes and four replicates per genotype $\mathrm{x}$ environment combination. Data for seeds
\end{abstract}


cotton productivity were analyzed by AMMI and GGE biplot methods. Both methods were concordant in the discrimination of environments and genotypes for phenotypic stability. The genotypes BRS ARAÇÁ and LD 05 CV had high seed cotton productivity and phenotypic stability, and could be grown in all environments across Mato Grosso State.

Key words: AMMI; GGE biplot; GE interaction; Gossypium hirsutum

\section{INTRODUCTION}

Upland cotton (Gossypium hirsutum L.r. latifolium Hutch.) is an economically important crop in Brazil, which is the world's fifth largest seed cotton producer, with 3.9 million tons produced in the 2014/15 crop. Production is concentrated in the State of Mato Grosso primarily in the municipalities of Primavera do Leste and Sapezal (CONAB, 2015).

Suinaga et al. (2006) reported that the cultivars Delta Opal and BRS Cedro are the most common in the State of Mato Grosso, as they bring together high seed cotton productivity, fiber percentage, and phenotypic stability. However, other cultivars, such as Araça BRS, BRS Buriti, FMT 701, and NUOPAL are also widely cultivated as they have high yield potential (Galbieri et al., 2011).

The breeding program of EMBRAPA Cotton aims to develop more productive genotypes with higher-quality fibers. To achieve this, a large number of genotypes $(\mathrm{G})$ is tested annually in different environments (E), before final recommendation and multiplication. In most cases, these environments vary substantially, and there are interactions between genotypes and environments (GE), that arise from differential genotypic responses to the environment. Understanding GE interactions affords an assessment of the real impact of selection and ensures greater reliability when recommending genotypes to maximize productivity and other agronomic traits of interest in a specific location or group of environments (Cruz et al., 2014).

Despite its importance, a simple GE interaction analysis does not provide complete and accurate information about the behavior of each genotype across varying environments. Therefore, it is necessary to analyze adaptability and phenotypic stability, to identify genotypes with predictable behavior that are responsive to environmental variation in specific or general conditions. Recent methods include the AMMI model (Gauch and Zobel, 1988), which is a statistical method for understanding the structure of interactions between genotypes and environments, and the GGE biplot model (Yan et al.,2000), which considers the sum of the main effect of the genotype and the genotype and environment interaction. Both analyses are based on biplot graphs and represent a data matrix.

The GGE biplot model is best suited to identifying mega-environments, selecting representative and discriminative environments, and appointing more adapted and stable genotypes to specific environments (Yan, 2011). In contrast, AMMI analysis can be used efficiently for identifying superior environmental conditions for the agricultural holding (selection of growing regions) and higher mean performance genotypes (Gauch et al., 2008).

To date, the GGE biplot method has been used to investigate GE interactions in several crops, but has not been applied to upland cotton in Brazil. Thus, the aim of this study is to investigate the association between AMMI and GGE biplot methods and select cotton genotypes that simultaneously contain high seed cotton yield and stability in environments of Mato Grosso State. 


\section{MATERIAL AND METHODS}

Eight cotton cultivar competition experiments were conducted during the 2008/2009 crop season in Mato Grosso State. Soil and climate features of each environment are shown in Table 1. The experimental design was a randomized complete block with 16 genotypes (BRS ARAÇA, BRS BURITI, BRS 286, FMT 701, FM 993, FM 910, DELTA OPAL, IPR JATAI, LD CV 05, LD CV 02, BRS CEDRO, NUOPAL, CNPA MT 05 1245, CNPA MT 04 2080, CNPA MT 04 2088, and BRS 293) and four replicates of each genotype x environment combination. Each experimental unit consisted of four rows $5 \mathrm{~m}$ long, spaced $0.9 \mathrm{~m}$ apart, with a density of 9 plants $/ \mathrm{m}$. In each experimental unit, seed cotton yield was evaluated in two central rows, corrected to $13 \%$ moisture, and extrapolated to $\mathrm{kg} / \mathrm{ha}$.

\section{Table 1. Edaphoclimatic features of the eight tested environments.}

\begin{tabular}{l|l|c|c|c|c}
\hline Environments & Abbreviation & Altitude $(\mathrm{m})$ & Latitude & Longitude & Annual rainfall $(\mathrm{mm})$ \\
\hline Primavera do Leste & PVA & 636 & $15^{\circ} 33^{\prime}$ & $54^{\circ} 17^{\prime}$ & 1713 \\
\hline Pedra Preta & PET & 850 & $16^{\circ} 37^{\prime}$ & $54^{\circ} 28^{\prime}$ & 1558 \\
\hline Campo Verde & CV & 736 & $15^{\circ} 32^{\prime}$ & $55^{\circ} 10^{\prime}$ & 1529 \\
\hline Lucas do Rio Verde & LRV & 399 & $13^{\circ} 03^{\prime}$ & $55^{\circ} 55^{\prime}$ & 1970 \\
\hline Sapezal & SAP & 387 & $12^{\circ} 59^{\prime}$ & $58^{\circ} 45^{\prime}$ & 2082 \\
\hline Campo Novo dos Parecis & CNP & 564 & $13^{\circ} 40^{\prime}$ & $57^{\circ} 53^{\prime}$ & 1939 \\
\hline Nova Ubiratâ & NUB & 396 & $13^{\circ} 00^{\prime}$ & $55^{\circ} 15^{\prime}$ & 1990 \\
\hline Primavera do Leste II & PVA II & 636 & $15^{\circ} 33^{\prime}$ & $54^{\circ} 17^{\prime}$ & 1713 \\
\hline
\end{tabular}

Seed cotton yield data for each genotype were analyzed individually with ANOVA, with genotypes as fixed effects and the environments as random effects. The relationship between the largest and smallest MS of the residuals from the individual ANOVAs did not exceed the ratio 7:1, permitting a joint analysis of trials (Banzatto and Kronka, 2006). Data were then analyzed for adaptability and stability with the AMMI and GGE biplot methods.

For the AMMI biplot analysis, we considered genotypes and environments as fixed effects and the model was specified according to the equation:

$$
Y_{i j}=\mu+g_{i}+a_{j}+\sum_{k=1}^{n} \lambda_{k} \gamma_{i k} \alpha_{j k}+\rho_{i j}+\bar{\varepsilon}{ }_{i j} \quad \text { (Equation 1) }
$$

where in: $\mathrm{Y}_{\mathrm{ij}}$ is the mean response of the $i$-th genotype $(i=1,2, \ldots, \mathrm{G}$ genotypes $)$ in the $j$-th environment $\left(j=1,2, \ldots\right.$, E environments); $\mu$ is the overall mean of the trials; $\mathrm{g}_{\mathrm{i}}$ is the effect of the $i$-th genotype; $a_{1}$ is the effect of the $j$-th envrionment; $\lambda_{\mathrm{k}}$ is the $k$-th singular value (scalar) of the original interaction matrix (denoted by GE); $\gamma_{\mathrm{ik}}$ is the element correspondent to the $i$-th genotype in the $k$-th column of the GE matrix singular vector; $\alpha_{\mathrm{jk}}$ is the element correspondent to the $j$-th environment in the $k$-th line of the GE matrix singular vector; $\rho_{\mathrm{ij}}$ is the noise associated with the term $(g e)_{i j}$ of the classical interaction of genotype $i$ with the environment $j$; and $\bar{\varepsilon}_{\mathrm{ij}}$ is the mean experimental error.

The GGE biplot model was specified according to the equation:

$$
Y_{i j}-y_{j}=y_{l} \varepsilon_{i l} \rho_{j l}+y_{2} \varepsilon_{i 2} \rho_{j 2}+\varepsilon_{i j}
$$

(Equation 2) 
where in: $y_{i j}$ is the mean population yield of the population of order $i$ in the environment of order $j ; y_{j}$ is the overall mean of genotypes in the environment $\mathrm{j} ; y_{l} e_{i l} r_{i l}$ is the first principal component (PC1); $y_{2} e_{i 2} r_{j 2}$ is the second principal component (PC2); $y_{1}$ and $y_{2}$ are the eigenvalues associated with IPCA1 and IPCA2, respectively; $e_{1}$ and $e_{2}$ are the values of PC1 and PC2, respectively, of the genotype of order $\mathrm{i} ; r_{j 1}$ and $r_{j 2} \mathrm{~s}$ are the values of $\mathrm{PC} 1$ and $\mathrm{PC} 2$, respectively, for the environment of order $\mathrm{j}$; and $e_{i j}$ is the error associated with the model of the $\mathrm{i}-\mathrm{th}$ genotype and j-th environment (Yan et al., 2000). Analyses used the Agricolae and GGEGui packages implemented in R software (R Development Core Team, 2015).

\section{RESULTS AND DISCUSSION}

In the joint analysis (Table 2), all effects were significant $(\mathrm{P} \leq 0.05)$, indicating contrasts between environments and differential genotypic responses to environmental effects. This was confirmed by the edaphoclimatic conditions of each environment (Table 1) that show differences in altitude, latitude, and longitude, and climatic effects, such as rainfall and temperature. Similar significant differences in the effects of G, E, and GE interaction were obtained by Silva Filho et al. (2008), Souza et al. (2006), and Suinaga et al. (2006) when evaluating cotton genotypes in multi-environment trials in Brazil. Significant GE interactions for seed cotton yield indicated that analyzes of adaptability and stability were appropriate as edaphoclimatic factors had the greatest influence on genotypes.

Table 2. Summary of joint ANOVA of seed cotton yield of 16 genotypes tested in eight environments.
\begin{tabular}{l|c|c}
\hline Components of variation & Degrees of freedom & Mean square \\
\hline Blocks/Environments & 24 & $1,569,116.36$ \\
\hline Genotypes (G) & 15 & $2,247,856.24^{*}$ \\
\hline Environments (E) & 7 & $76,415,198.24^{*}$ \\
\hline GE & 105 & $659,283.76^{*}$ \\
\hline Error & 360 & $346,994.25$ \\
\hline Coefficient of variation (\%) & - & 12.58 \\
\hline
\end{tabular}

* Significant at $1 \%$ probability by the F-test.

In the AMMI1 biplot (Figure 1A), stability was interpreted from the ordinate axis, with scores close to zero considered as stable genotypes and environments. Adaptability was interpreted from the abscises axis, where the means of genotypes and environments are plotted (Gauch and Zobel, 1988). The genotypes DELTA OPAL (G7), and BRS BURITI (G2) were the most unstable and contributed the most towards GE interaction (Figure 1).The genotypes BRS ARAÇÁ (G1), LD CV 05 (G9), and LD CV 02 (G10), had lower coordinates on the PC1 axis (were most stable), and therefore contributed the least towards GE interaction. BRS ARAÇÁ (G1) and LD CV 05 (G9) performed above the overall mean (Table 3), demonstrating adaptation to all environments and were therefore classified as generalists.

The environment Pedra Preta (PET) had higher mean yield (Table 3 ) and proved to be more unstable (higher score on the PC1 axis). Environments Campo Novo dos Parecis (CNP), Sapezal (SAP), and Nova Ubiratã (NUB) presented the lowest scores on the PC1 axis (Figure 1), and were thus considered the most stable. According to Oliveira et al. (2003), environmental stability is of great importance as it indicates the reliability of the order of genotypes in a specific test environment, compared to the ranking of means of tested environments. 

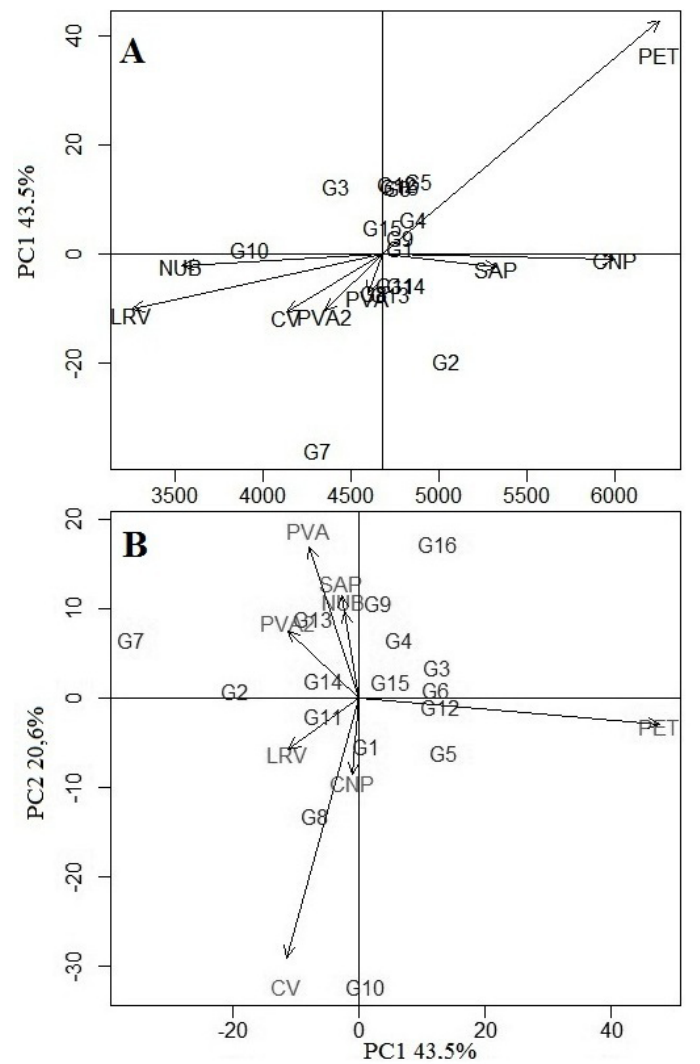

Figure 1. A. AMMI1 biplot of principal effects and GE interactions of seed cotton yield (kg/ha) and (B) AMMI2 biplot of the first principal component of the interaction (PC1) $\mathrm{x}$ second principal component of the interaction (PC2) of 16 genotypes, tested in eight environments (described in Table 1) across Mato Grosso.

Table 3. Mean seed yield $(\mathrm{kg} / \mathrm{ha})$ of 16 cotton genotypes in eight tested environments and overall mean of genotypes and environments ${ }^{1}$.

\begin{tabular}{l|l|l|l|l|l|l|l|l|l|l}
\hline Code & Genotype & PVA & PET & CV & LRV & SAP & CNP & NUB & PVA II & Mean \\
\hline G1 & BRS ARAÇA & 4672 & 6505 & 4051 & 4086 & 5132 & 6248 & 3190 & 4414 & 4787 \\
\hline G2 & BRS BURITI & 4598 & 5636 & 4609 & 3937 & 6119 & 6313 & 4124 & 5012 & 5044 \\
\hline G3 & BRS 286 & 4249 & 6541 & 3622 & 2854 & 5006 & 5677 & 3642 & 3763 & 4419 \\
\hline G4 & FMT 701 & 4842 & 6688 & 4192 & 2995 & 5371 & 6023 & 4283 & 4484 & 4860 \\
\hline G5 & FM 993 & 4400 & 7151 & 4341 & 3257 & 5682 & 6303 & 3241 & 4741 & 4889 \\
\hline G6 & FM 910 & 4271 & 6953 & 3975 & 3338 & 5474 & 5930 & 3628 & 4594 & 4770 \\
\hline G7 & DELTA OPAL & 4827 & 4200 & 4072 & 3255 & 4888 & 5401 & 3409 & 4489 & 4318 \\
\hline G8 & IPR JATAI & 4435 & 5902 & 4811 & 3084 & 5344 & 5923 & 3387 & 4176 & 4633 \\
\hline G9 & LD CV 05 & 4738 & 6475 & 3692 & 3501 & 5803 & 6082 & 3403 & 4562 & 4782 \\
\hline G10 & LD CV 02 & 3180 & 5573 & 4379 & 2550 & 4083 & 5760 & 2725 & 3145 & 3924 \\
\hline G11 & BRS CEDRO & 4574 & 6060 & 4212 & 3712 & 5504 & 6093 & 3560 & 4348 & 4758 \\
\hline G12 & NUOPAL & 5164 & 7096 & 4361 & 3172 & 5024 & 5629 & 3287 & 4378 & 4764 \\
\hline G13 & CNPA MT 05 1245 & 5098 & 5846 & 3826 & 2904 & 5396 & 6758 & 3312 & 4676 & 4727 \\
\hline G14 & CNPA MT 04 2080 & 5026 & 6177 & 4482 & 3370 & 5502 & 5765 & 3614 & 4600 & 4817 \\
\hline G15 & CNPA MT 04 2088 & 4686 & 6445 & 3999 & 3087 & 5192 & 6150 & 3697 & 4161 & 4677 \\
\hline G16 & BRS 293 & 4797 & 6821 & 3575 & 3030 & 5747 & 5904 & 4177 & 4138 & 4774 \\
\hline Mean & & 4597 & 6254 & 4137 & 3258 & 5329 & 5997 & 3542 & 4355 & 4684 \\
\hline
\end{tabular}

${ }^{1}$ Environments described in Table 1. 
AMMI2 biplot (Figure 1B) shows the stability of genotypes and environments, as well as specific GE interactions. The zone of stability corresponds to the central region of the biplot, at the intersection of zero scores on the first and second principal components axes. Genotypes and environments close to each other in any graph area represent specific adaptation of a genotype to the environment (Gauch and Zobel, 1988). Specific interactions were observed between LD CV 05 (G9) and Nova Ubiratã (NUB) and Sapezal (SAP), CNPA MT 051245 (G13) and Primavera do Leste II (PVA2), BRS Araça and Campo Novo dos Parecis (CNP), and BRS Cedro and Lucas do Rio Verde (LRV).

Figure 2 shows a polygon connecting the genotypes BRS BURITI (G2), Delta Opal (G7), LD CV 02 (G10), BRS 286 (G3), and FM 993 (G5) that are furthest from the biplot point of origin. These genotypes have the highest vectors in their respective directions; the vector length and direction represents the extension of the genotypes response to the tested environments. All other genotypes are contained within the polygon and have smaller vectors, i.e., they are less sensitive to interaction with the environment in each sector (Yan and Rajcan, 2002). The vectors from the center of the biplot $(0,0)$ divide the graph into four sectors. Similar results were observed by Mattos et al. (2013), who observed six sectors of graph division when assessing the stem yield of sugarcane genotypes via the GGE biplot method.

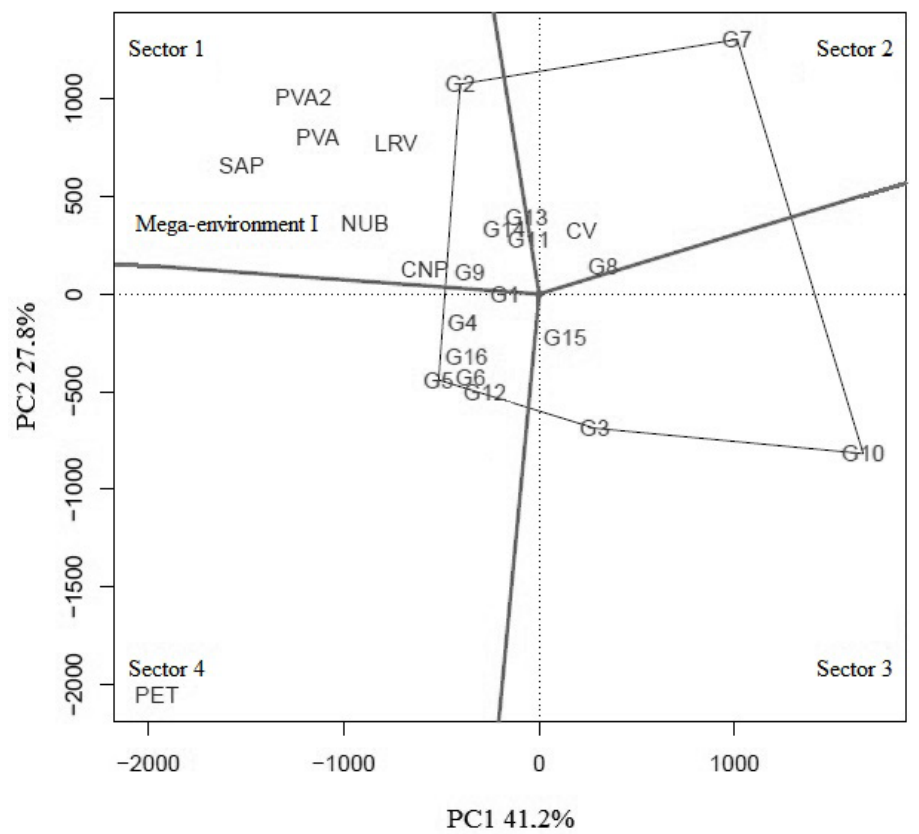

Figure 2. Sectors and mega-environments obtained from the GGE biplot model of seed cotton yield of 16 genotypes tested in eight environments (described in Table 1) across Mato Grosso.

Criteria for the formation of mega-environments are: significant differences between the genotypes in different environments; and variation, which is observed graphically, in one group must be significantly greater than in the other (Yan and Rajcan, 2002). The polygon from the GGE biplot (Figure 2) grouped the sites Campo Novo dos Parecis (CNP), Lucas do Rio 
Verde (LRV), Primavera do Leste (PVA and PVA2), Nova Ubiratã (NUB), and Sapezal (SAP) in the mega-environment 1. The genotype BRS BURITI (G2) present at the vertex, achieved the highest means of seed cotton yield in the environments SAP and PVA2, and the highest mean among all of the genotypes (Table 3 ). When genotypes give rise to polygon vertices, but do not contain any clustered environments, they have low yield and are considered unsuited to the groups of tested environments (Karimizadeh et al., 2013). Thus, the genotypes BRS 286 (G3), LD CV 02 (G10), and CNPA MT 042088 (G15), located in Sector 3, are unsuitable for recommendation in these sites.

Seed cotton yield and stability of genotypes were assessed from the coordination of the middle environment (CAE) (Figure 3). Higher genotype projections on the CAE ordinate axis indicate more unstable genotypes, and a greater interaction with the environment (Yang et al., 2009). The genotypes BRS ARAÇÁ (G1) and LD CV 05 (G9) were notable for their phenotypic stability (Figure 3), showing high mean yield over all of the environments (Table 3). In contrast, the genotypes Delta Opal (G7) and BRS BURITI (G2) were the most unstable. Importantly, we note that the classification of genotypes based on phenotypic stability was similar from both methods used in this study, corroborating previous results (Balestre et al., 2009; Miranda et al. 2009; Camargo-Buitrago et al., 2011; Mattos et al., 2013; Sousa et al., 2015).

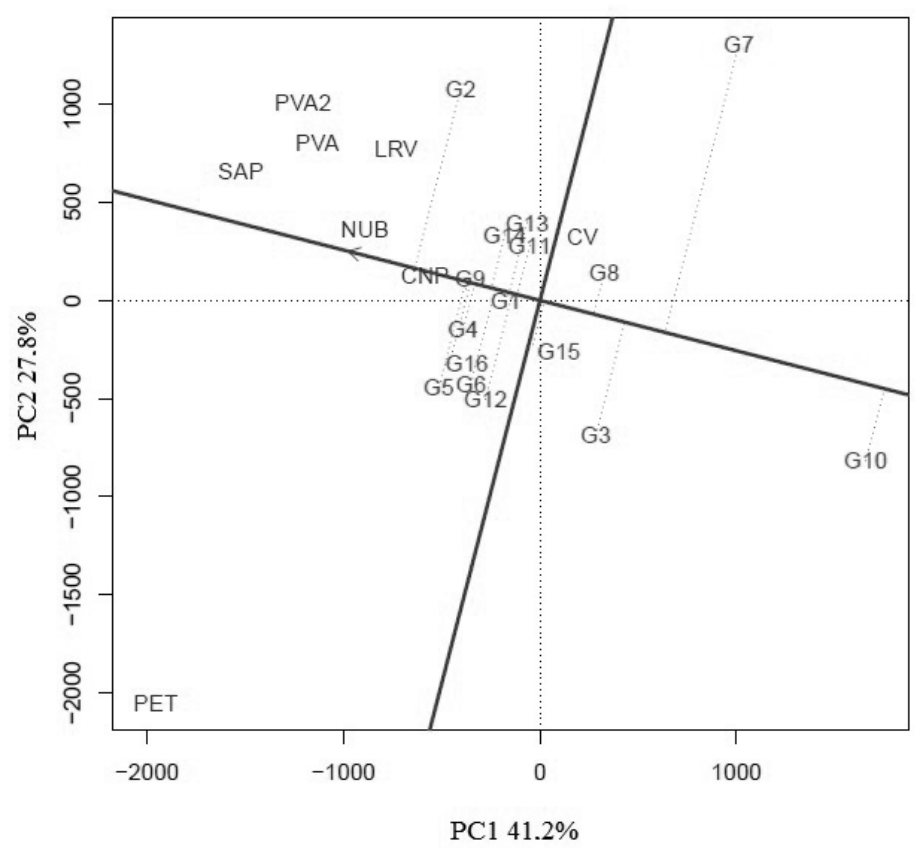

Figure 3. Mean versus stability assessed from the GGE biplot model of seed cotton yield of 16 genotypes tested in eight environments (described in Table 1) across Mato Grosso.

An ideal genotype should have a mean seed cotton yield that is consistently high over all environments of interest. This ideal genotype is graphically defined by the longest vector in $\mathrm{PC} 1$ and $\mathrm{PC} 2$ without projections, and represented by the arrow in the center of concentric circles (Yan and Rajcan, 2002). Although this genotype is more of a representative model, it is used as a reference for assessing genotypes. Thus, the genotypes LD CV 05 (G9) and FMT 
701 (G4), located in the third and fourth concentric circles, respectively, are closest to the ideal in terms of high seed cotton yield and phenotypic stability (Figure 4).

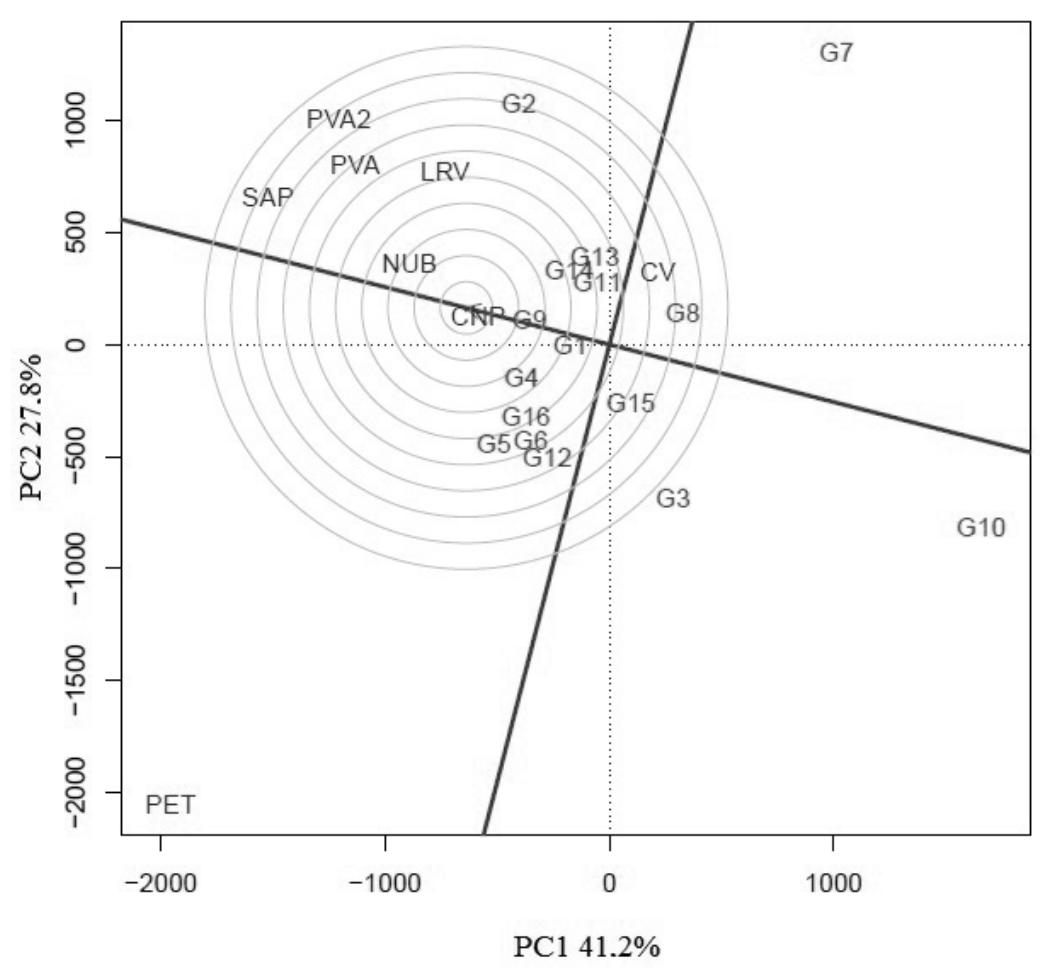

Figure 4. Classification of 16 genotypes from the GGE biplot model of seed cotton yield in eight environments (described in Table 1) across Mato Grosso.

Figure 5 shows the relationship between the seed cotton yield and the stability from the vector view of environments, in which environments are connected by vectors with the biplot origin. In environments with small vectors, the yield stability is high (Yang et al., 2009). Thus, the environment Campo Novo dos Parecis (CNP) contributed less towards the GE interaction, while Pedra Preta (PET) proved to be more unstable.

Yang et al. (2009) concluded that an ideal environment should have a high PC1 score (greater power to discriminate genotypes from main genotype effects) and zero PC2 score (more representative of all the other environments). Similarly, the ideal environment is only a reference for selecting sites for multi-environment trials. Thus, the environment Sapezal (SAP) has, for the genotypes tested, the greatest ability to discriminate genotypes, and favor the selection of superior genotypes.

AMMI and GGE biplot methods were concordant in discriminating environments and genotypes for phenotypic stability. The genotypes BRS ARAÇÁ (G1) and LD CV 05 (G9) achieved high seed cotton yield and phenotypic stability in all environments across the State of Mato Grosso. 


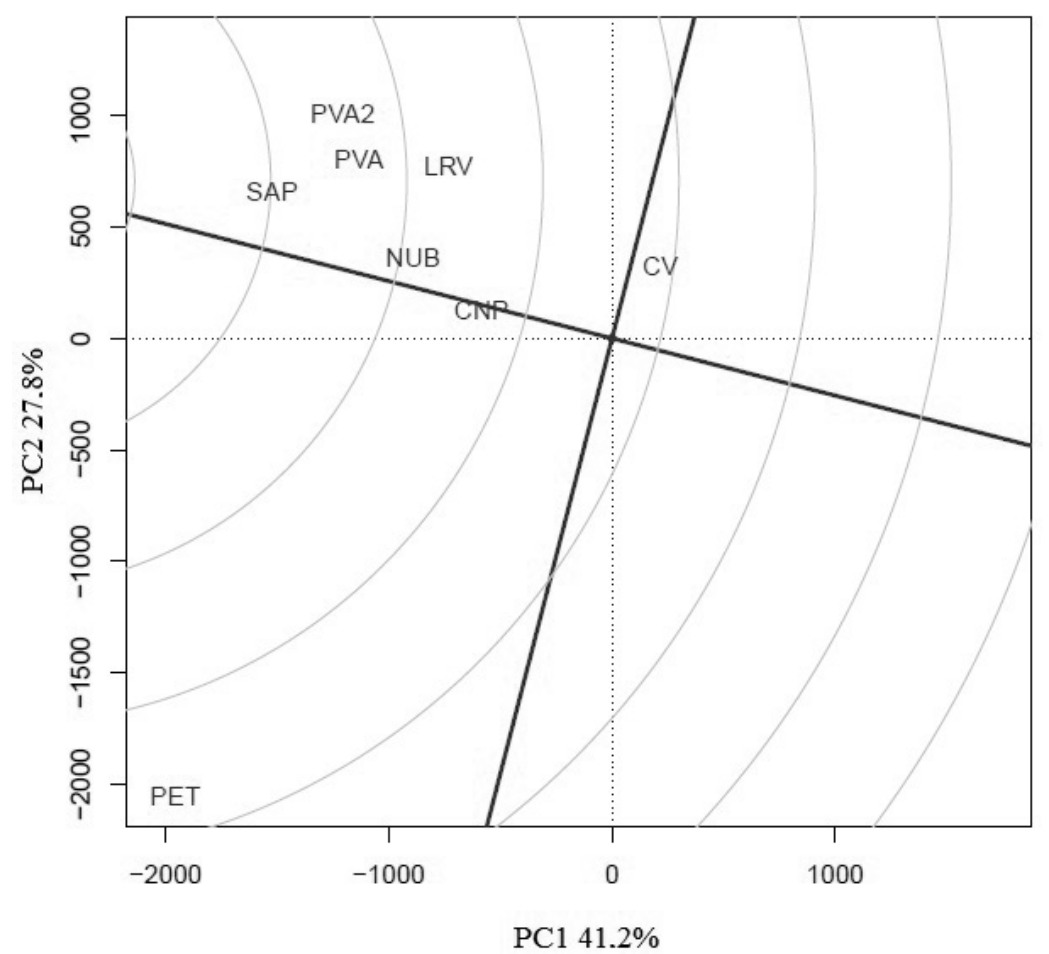

Figure 5. Relationship between the environments obtained from the GGE biplot model of seed cotton yield of 16 genotypes tested in eight environments (described in Table 1) across Mato Grosso.

\section{Conflicts of interest}

The authors declare no conflict of interest.

\section{ACKNOWLEDGMENTS}

Research supported by Coordenação de Aperfeiçoamento de Pessoal de Nível Superior (CAPES) and Conselho Nacional de Desenvolvimento Científico e Tecnológico (CNPq).

\section{REFERENCES}

Balestre M, Von Pinho RG, Souza JC and Oliveira RL (2009). Genotypic stability and adaptability in tropical maize based on AMMI and GGE biplot analysis. Genet. Mol. Res. 8: 1311-1322. http://dx.doi.org/10.4238/vol8-4gmr658

Banzatto DA and Kronka SN (2006). Experimentação agrícola. FUNEP, Jaboticabal.

Camargo-Buitrago I, Quiros-McIntire E and Gordón-Mendoza R (2011). Identificación de mega-ambientes para potenciar el uso de genótipos superiores de arroz en Panamá. Pesq. Agropec. Bras. 46: 1061-1069.

CONAB (2015). Companhia Nacional de Abastecimento. Acompanhamento de Safra Brasileira: grãos, décimo segundo levantamento, Setembro/2015. Available at [http://www.conab.gov.br]. Accessed November 30, 2015.

Cruz CD, Carneiro PCS and Regazzi AJ (2014). Modelos biométricos aplicados ao melhoramento genético. Editora UFV, Viçosa. Galbieri R, Fuzatto MG, Cia E, Welter AM, et al. (2011). Desempenho de genótipos de algodoeiro na presença ou não de rotação de cultura com Crotalaria spectabilis, em área infestada com Meloidogyne incógnita. Trop. Plant Path. 36: 
303-307. http://dx.doi.org/10.1590/S1982-56762011000500005

Gauch HG, Jr. and Zobel RW (1988). Predictive and postdictive success of statistical analyses of yield trials. Theor. Appl. Genet. 76: 1-10. http://dx.doi.org/10.1007/BF00288824

Gauch HG, Piepho HP and Annicchiarico P (2008). Statistical Analysis of Yield Trials by AMMI and GGE: Further considerations. Crop Sci. 48: 866-889. http://dx.doi.org/10.2135/cropsci2007.09.0513

Karimizadeh R, Mohammadi M, Sabaghni N, Mahmoodi SA, et al. (2013). GGE Biplot Analysis of Yield Stability in Multi-environment Trials of Lentil Genotypes under Rainfed Condition. Not. Sci. Biol. 5: 256-262.

Mattos PHC, Oliveira RA, Bespalhok Filho JC, Daros E, et al. (2013). Evaluation of sugarcane genotypes and production environments in Paraná by GGE biplot and AMMI analysis. Crop Breed. Appl. Biotechnol. 13: 83-90. http://dx.doi. org $/ 10.1590 /$ S1984-70332013000100010

Miranda GV, Souza LV, Guimarães LJM, Namorato H, et al. (2009). Multivariate analyses of genotype $\times$ environment interaction of popcorn. Pesq. Agropec.. Bras. 44: 45-50. http://dx.doi.org/10.1590/S0100-204X2009000100007

Oliveira AB, Duarte JB and Pinheiro JB (2003). Emprego da análise AMMI na avaliação da estabilidade produtiva em soja. Pesq. Agropec. Bras. 38: 357-364. http://dx.doi.org/10.1590/S0100-204X2003000300004

R Development Core Team (2015). R: a language and environment for statistical computing. Vienna: R Foundation for Statistical Computing. http://www.R- project.org. Accessed April 15, 2015.

Silva Filho JL, Morello CL, Farias FJC, Lamas FM, et al. (2008). Comparação de métodos para avaliar a adaptabilidade e estabilidade produtiva em algodoeiro. Pesq. Agropec. Bras. 43: 349-355. http://dx.doi.org/10.1590/S0100$\underline{204 X 2008000300009}$

Sousa LB, Hamawaki OT, Nogueira AP, Batista RO, et al. (2015). Evaluation of soybean lines and environmental stratification using the AMMI, GGE biplot, and factor analysis methods. Genet. Mol. Res. 14: 12660-12674. http:// dx.doi.org/10.4238/2015.October.19.10

Souza AA, Freire EC, Bruno RLA, Carvalho LP, et al. (2006). Estabilidade e adaptabilidade do algodoeiro herbáceo no Cerrado do Mato Grosso e Mato Grosso do Sul. Pesq. Agropec. Bras. 41: 1125-1131. http://dx.doi.org/10.1590/ $\underline{\mathrm{S} 0100-204 X 2006000700008}$

Suinaga FA, Bastos CS and Pacifici Rangel LE (2006). Phenotypic adaptability and stability of cotton cultivars in Mato Grosso State, Brazil. Pesq. Agropec. Trop. 36: 145-150.

Yan W (2011). GGE Biplot vs AMMI Graphs for Genotype-by-Environment Data Analysis. J. Indian Soc. Agric. Stat. 65: 181-193.

Yan W and Rajcan I (2002). Biplot Analysis of Test Sites and Trait Relations of Soybean in Ontario. Crop Sci. 42: 11-20. http://dx.doi.org/10.2135/cropsci2002.0011

Yan W, Hunt LA, Sheng Q and Szlavnics Z (2000). Cultivar Evaluation and Mega-Environment Investigation Based on the GGE Biplot. Crop Sci. 40: 597-605. http://dx.doi.org/10.2135/cropsci2000.403597x

Yang RC, Crossa J, Cornelius PL and Burgueño J (2009). Biplot analysis of genotype $\mathrm{x}$ environment interaction: proceed with caution. Crop Sci. 49: 1564-1576. http://dx.doi.org/10.2135/cropsci2008.11.0665 